\title{
Profiling of Patients with Temporomandibular Disorders: Experience of One Tertiary Care Center
}

\section{Profiliranje bolesnika s temporomandibularnim poremećajima: iskustva tercijarnog centra}

\author{
${ }^{1}$ Department of Removable Prosthodontics, School of Dental Medicine, University of Zagreb \\ Zavod za mobilnu protetiku Stomatološkog fakulteta Sveučilišta u Zagrebu \\ 2 School of Dental Medicine, alumna \\ Alumna Stomatološkog fakulteta Sveučilišta u Zagrebu \\ ${ }^{3}$ Department of Dentistry, Clinical Hospital Center Zagreb, Croatia \\ Klinika za stomatologiju Kliničkog bolničkog centra Zagreb
}

\begin{abstract}
Objectives: The aim of this study was to assess typical and most prevalent characteristics of patients suffering from temporomandibular disorders (TMD) by a retrospective assessment of their medical records. Material and Methods: Demographic data and data on the characteristics of TMD were collected from the existing medical documentation of 304 TMD patients ( 250 females and 54 males) who had been referred to the Department of Dentistry, Clinical Hospital Center Zagreb from October 2016 to October 2020 due to temporomandibular pain. For the purpose of analysis, three age groups were formed: i) "children and adolescents" (up to 19 years of age); ii) "middle age" (from 20 to 50 years of age); iii) "older age" ( $>50$ year- olds). A two-step cluster analysis was performed with the aim of classifying TMD patients into homogenous groups. Results: The mean age of patients whose data were included in the study was $33.8 \pm 16.66$, with a significantly higher age in the group of women $(p<0.001)$. Most of the patients had chronic pain $(67.4 \%)$, with the ratio in favor of chronic patients being significantly higher in women than in men $(p=0.001)$. Data on parafunctional behavior were confirmed in $14.5 \%$ of patients. Data on the onset of symptoms during/just after orthodontic treatment were present in $14.5 \%$ of patients. Data on spontaneous pain, assessed with a visual analogue scale, were recorded in 87 patients, with a mean of $6.14 \pm 1.79$ and with the highest pain in the "older age" group. Physical therapy was the most common therapeutic modality $(56.3 \%)$ followed by an occlusal splint (40.5\%). The analysis revealed 5 different clusters in the TMD patient data set. Conclusions: Our results are largely in line with current epidemiological knowledge on TMD. Women predominated in all age groups and most of the patients experienced chronic pain. Classifying patients into homogeneous groups using the clustering method could provide better identification of subgroups of conditions that mainly occur together in these patients, thus providing the basis for more specific management.
\end{abstract}

Received: March 7, 2021

Accepted: May 14, 2021

Address for correspondence Iva Z. Alajbeg

University of Zagreb

School of Dental Medicine Department of Removable Prosthodontic

Gundulićeva 5, 10000 Zagreb

ialajbeg@sfzg.hr

\section{Introduction}

In clinical practice, patients who report difficulties that can be associated with some form of temporomandibular disorders (TMD), a heterogeneous group of pathological conditions involving the temporomandibular joint (TMJ), masticatory muscles, or both are increasingly encountered (1). The most common symptoms of TMD include muscle and/ or TMJ pain that occurs or intensifies during functions of the mandible, sounds in the TMJ, and difficult and/or limited mouth opening, which may be accompanied by deviation from a straight line (deviation or uncorrected deviation) (2).

Risk factors associated with the onset of TMD are emotional stress, trauma, oral parafunctional behavior, and deep painful stimuli $(3,4)$. Scientific research has repeatedly confirmed that occlusion, which in the past was considered one
Uvod

U kliničkoj praksi često susrećemo pacijente koji dolaze zbog poteškoća povezanih s nekim oblikom temporomandibularnih poremećaja (TMP). Riječ je o heterogenoj skupini patoloških stanja koja zahvaćaju temporomandibularni zglob (TMZ), žvačne mišiće ili obje strukture (1). Najčešći simptomi su bolovi u mišićima i/ili TMZ-u koji se pojavljuju ili pojačavaju tijekom funkcije donje čeljusti, zvukovi u TMZ-u te otežano i/ili ograničeno otvaranje usta koje katkad može biti praćeno skretanjem čeljusti u odnosu u odnosu na središnju liniju otvaranja (tzv. devijacija i defleksija) (2).

Čimbenici rizika povezani s pojavom TMP-a su emocionalni stres, trauma, oralne parafunkcijske navike i duboki bolni podražaji $(3,4)$. U znanstvenim istraživanjima nekoliko je puta potvrđeno da okluzija, koja se u prošlosti smatrala 
of the main causes of TMD, has no role in the development of TMD, but may pose a problem in hypervigilant patients (5).

Pain and limitations of the mandibular movement are the most commonly reported signs/symptoms by patients who seek for help (6). Additionally, it is very common for patients to report various comorbid conditions such as depression, anxiety and other psychological disorders along with primary ailments (7). The latter may be a direct consequence of chronic orofacial pain but is also considered one of the risk factors that can affect the intensity and course of TMD (8). Tension headaches, migraines, fibromyalgia, and lower back pain are comorbidities also mentioned in the literature (9). Somatization and psychological problems are more often associated with chronic pain. Neuroplasticity is involved in chronic pain development (10). The most important consequence of these neuroplastic changes in chronic pain is reduced filtering ability of central sensory neurons in the brain and spinal cord resulting in wrong interpretation of noxious stimuli that can be exaggerated (secondary hyperalgesia) or misinterpreted.

The exact prevalence of TMD in the general population varies greatly in the literature and ranges from 3-33\%, which might be the consequence of considerable variations in diagnostic protocols $(11,12)$. Using standardized diagnostic criteria such as RDC/TMD (Research Diagnostic Criteria for TMD) and DC/TMD (Diagnostic Criteria for Temporomandibular Disorders), recent research is providing increasingly accurate data (13). Today, the prevalence of TMJ pain in the general population is considered to be $4-10 \%$ and $3-17 \%$ for muscle pain. Furthermore, the incidence of TMD is highly age-dependent with prevalence being highest at 20 40 years of age (14).

With respect to gender, TMD is more common in women (15). The reasons for gender inequality are still not fully elucidated (16). It is hypothesized that the presence of estrogen receptors may be a predisposition to TMJ dysfunction and degradation, i.e., cartilage destruction (17).

It is interesting to note that in clinical practice, more and more children and adolescents are reporting symptoms of TMD, and very often patients in the middle of the active phase of removable and fixed orthodontic therapy. An increasing number of patients, who are looking for a solution for acute and chronic forms of TMD, point to the need for better profiling in order to provide them with an individualized approach to treatment and the most precise therapy possible.

The aim of this study was to assess typical and most prevalent characteristics of patients suffering from TMD by a retrospective assessment of their medical records and to classify patients into homogeneous groups, by means of cluster analysis, based on their demographics, primary diagnosis, chronicity and risk factors.

\section{Material and Methods}

This study was a retrospective assessment of medical records of 304 TMD patients (250 females and 54 males) treated at the Department of Dentistry, Clinical Hospital Center Zagreb from October 2016 to October 2020. jednim od glavnih uzročnih čimbenika TMP-a, nema ulogu u njegovu razvoju, ali može činiti problem hipervigilantnim pacijentima (5).

Simptomi zbog kojih pacijenti najčešće traže pomoć su bol i ograničena pokretljivost donje čeljusti (6). Uz primarne tegobe, pacijenti često prijavljuju različita popratna stanja poput depresije, anksioznosti i drugih psiholoških poremećaja (7). Psihološki poremećaji mogu biti izravna posljedica kronične boli, ali se također smatraju jednim od čimbenika rizika koji mogu utjecati na intenzitet i tijek TMP-a (8). U literaturi se također spominju tenzijska glavobolja, migrena, fibromialgija i bolovi u donjem dijelu leđa kao stanja koja se često pojavljuju uz TMP (9). Somatizacija i psihološki problemi uglavnom su povezani s kroničnom boli. U razvoj kronične boli uključeni su različiti procesi neuroplastičnosti (10). Najvažnija posljedica neuroplastičnih promjena u slučaju kronične boli jest smanjena sposobnost filtriranja podražaja, a to često rezultira pogrešnom interpretacijom štetnih podražaja kao pretjerano bolnih (sekundarna hiperalgezija).

Točna prevalencija TMP-a u općoj populaciji uvelike varira te se prema podatcima iz literature kreće u rasponu od 3 do $33 \%$, što je posljedica značajnih varijacija u dijagnostičkim protokolima $(11,12)$. Recentna istraživanja u kojima su za dijagnozu TMP-a korišteni standardizirani dijagnostički kriteriji (dijagnostički kriteriji za istraživanje temporomandibularnih poremećaja - DKI/TMP-a i dijagnostički kriterij za tempromandibularne poremećaje - DK/TMP) pružaju ipak mnogo preciznije podatke (13). Prevalencija boli TMZ-a u općoj populaciji iznosi od 4 do $10 \%$, a mišićna bol pojavljuje se kod 3 do $17 \%$ ispitanika. Nadalje, incidencija TMP-a ovisi o dobi, a prevalencija je najviša između 20. i 40. godine (14).

Temporomandibularni poremećaji češći su kod žena (15). Razlozi za spolnu nejednakost još nisu potpuno razjašnjeni (16). Pretpostavlja se da estrogenski receptori mogu biti predispozicija za disfunkciju i razgradnju TMZ-a, tj. uništavanje hrskavice (17).

Zanimljivo je da se u kliničkom radu zapaža sve više djece i adolescenata sa simptomima TMP-a, a vrlo često dolaze i pacijenti usred aktivne faze mobilne i fiksne ortodontske terapije. Sve veći broj pacijenata koji traži rješenje za akutne i kronične oblike TMP-a upućuje na to da je potrebno bolje profiliranje kako bi im se omogućio individualizirani pristup liječenju i što preciznija terapija.

Cilj ovog istraživanja bio je procijeniti tipične i najčešće karakteristike pacijenata koji boluju od temporomandibularnih poremećaja analizom njihove medicinske dokumentacije te ih svrstati u homogene skupine na temelju demografskih podataka, podatka o primarnoj dijagnozi, trajanju TMP-a i čimbenicima rizika.

\section{Materijal i metode}

Iz medicinske dokumentacije 304 pacijenta s TMP-om (250 žena i 54 muškarca), koji su bili upućeni u Kliniku za stomatologiju Kliničkog bolničkog centra Zagreb od listopada 2016. do listopada 2020. godine zbog temporomandibu- 
The conducted research was approved by the Ethics Committee of the School of Dental Medicine, University of Zagreb (05-PA-30-VIII-6/2019) and performed following the ethical standards of the Helsinki Declaration. This study has been supported by the Croatian Science Foundation Project "Genetic polymorphisms and their association with temporomandibular disorders" (No. IP-2019-04-6211).

\section{Description of the clinical examination protocol and therapy}

Patients' examinations were conducted by two calibrated experts in TMD diagnostics (IA and EV) (18).

While medical histories were taken from patients, examiners collected data about their reasons for seeking help, pain characterization (intensity, spontaneous pain, reported pain duration - TMD chronicity), limitation of the lower jaw (mouth opening, pain, and difficulties while eating, etc.), the existence of systemic diseases and previous pharmacotherapy use, awareness of oral parafunctional habits and data on previous orthodontic treatment. The clinical examination consisted of the evaluation of full dental status, analysis of panoramic imaging, palpation of the masticatory muscles, the lateral pole of TMJ, submandibular and retromandibular region. Measurements of pain-free mouth opening and unassisted mouth opening (MCO, MMO, respectively) were obtained, as well as the information about the existence of deflection and sounds in the joint. Methods for evaluation of spontaneous pain and measuring of $\mathrm{MCO}$ and $\mathrm{MMO}$ were described in our previous studies (18). All patients were clinically diagnosed according to DC/TMD diagnostic tree (13). If applicable, the diagnosis was confirmed by radiographic imaging.

After the clinical diagnosis had been established, it was decided which therapeutic option would be used. Physical therapy consisted of a set of recommended exercises that were performed by a patient (muscle massage, passive and active stretching, application of warm compresses) (19). The production and manufacturing of stabilization splint was described in our previous research (18). Pharmacotherapy mainly included analgesics, nonsteroidal anti-inflammatory drugs (NSAID) or a combination of NSAIDs/analgesics with benzodiazepines $(20,21)$. All patients received a thorough oral explanation of their condition with an emphasis on education about the nature of the present pain and various ways to deal with it.

\section{Collected data}

All data were extracted from the patient's medical records. Patients whose data were included in the study ranged between 8 to 83 years of age. For analysis purposes, three age groups were formed: i) "children and adolescents" (up to 19 years of age); ii) "middle age" (from 20 to 50 years of age); iii) "older age" ( $>50$ year olds).

TMD was considered acute if participants were experiencing symptoms for no more than 3 months prior to the first examination, or participants experienced new, previously non-existent, symptoms (i.e. pain or limited mouth opening) in the past 3 months, regardless of existing TMD histo- larne boli, prikupljeni su demografski podatci te podatci o karakteristikama TMP-a.

Istraživanje je odobrilo Etičko povjerenstvo Stomatološkog fakulteta Sveučilišta u Zagrebu (05-PA-30-VIII-6/2019) i provedeno je prema standardima Helsinške deklaracije. Ovaj rad dio je projekta Hrvatske zaklade za znanost Povezanost genskih polimorfizama s temporomandibularnim poremećajima (br. IP-2019-04-6211).

\section{Opis protokola kliničkog pregleda}

Preglede pacijenata obavljala su dva kalibrirana ispitivača, stručnjaka za dijagnostiku TMP-a (I. A. i E. V.) (18).

Tijekom uzimanja anamneze ispitivači su prikupljali podatke o razlogu dolaska, karakteru boli (intenzitet, vrsta boli, trajanje boli - kronicitet TMP-a), funkcijskim ograničenjima donje čeljusti (ograničeno otvaranje usta, bolovi, poteškoće tijekom jela, itd.), eventualnim sistemskim bolestima i korištenoj farmakoterapiji, svijesti o oralnim parafunkcijskim navikama te o dotadašnjem ortodontskom liječenju. Klinički pregled uključivao je analizu zubnog statusa i panoramske snimke, palpaciju žvačnih mišića, lateralnog pola TMZ-a, submandibularnog i retromandibularnog područja. Zabilježeni su podatci o iznosu bezbolnog otvaranja i iznosu maksimalnoga neasistiranoga otvaranja usta $(\mathrm{BO}, \mathrm{MNO}$, redom), te podatak pojavljuje li se defleksija pri otvaranju usta i zvukovi u zglobu. Metode procjene spontane boli, BO-a i MNO-a, opisane su u našoj prethodnoj studiji (18). Dijagnoza je postavljena prema protokolu dijagnostičkih kriterija za tempromandibularne poremećaje (DK/TMP) (13). U nekim je slučajevima potvrđena radiološkim snimkama.

Nakon postavljanja dijagnoze pacijentima je preporučena terapija koja je mogla uključivati fizikalnu terapiju, izradu stabilizacijske udlage te, prema potrebi, farmakoterapiju. Fizikalna terapija sastojala se od niza preporučenih vježbi koje je pacijent trebao obavljati kod kuće (masaža mišića, pasivno i aktivno istezanje, primjena toplih obloga) (19). Postupak izrade stabilizacijske udlage opisan je u našem prethodnom istraživanju (18). Od lijekova najčešće su se upotrebljavali analgetici, nesteroidni protuupalni lijekovi (NSAR) ili kombinacija NSAR-a/analgetika s benzodiazepinom $(20,21)$. Uz to, svi su pacijenti dobili detaljne usmene informacije o poremećaju s naglaskom na edukaciju o prirodi sadašnje boli i načinima suočavanja s njom.

\section{Prikupljeni podatci}

Pacijenti, čiji su podatci uključeni u studiju, bili su u dobi između 8 i 83 godine. Za potrebe analize formirane su tri dobne skupine: djeca i adolescenti (do 19 godina), srednja dob (od 20-50 godina); starija dob ( $>50$ godina).

Pacijenti kojima su se pojavili simptomi unatrag manje od tri mjeseca do trenutka prvog pregleda ili oni kojima su se pojavili novi, do tada nepostojeći simptomi (tj. bol ili ograničeno otvaranje usta) u posljednja 3 mjeseca, bez obzira na postojeću povijest TMP-a svrstani su u skupinu akutnih. Podjela na akutni i kronični TMP temeljila se na kriterijima Međunarodne udruge za istraživanje boli (engl. International 
ry. The division into acute and chronic pain was based on the International Association for the Study of Pain (IASP) which defines acute pain as the pain that occurs within 3 months, while chronic primary pain is the pain in one or more anatomical regions that persists or recurs for longer than 3 months and is associated with significant psychological stress and/or functional disability with symptoms that cannot be accounted for by another diagnosis (22).

A history of possible orthodontic therapy had been recorded. The data about the development of new symptoms during orthodontic therapy or immediately after the end of orthodontic therapy were taken into analysis. The presence of parafunctional behavior was recorded and included into analysis if data regarding daytime grinding and/or clenching were reported by the patient himself/herself or if data on nocturnal clenching were confirmed by another person (ie. parent, spouse, partner, sibling, roommate).

Conventional radiographs were of diagnostic value only when degenerative changes were obvious. Magnetic resonance imaging (MRI) of the TMJ was requested for a limited number of patients that were unresponsive to therapy or had severely limited mouth opening $(<30 \mathrm{~mm})$ considered to be of joint origin. Cone-beam computed tomography scans were analyzed only if previously performed.

The possible diagnoses, mainly based on clinical findings, were: myalgia, arthralgia, disc displacement with reduction (DDwR), disc displacement without reduction (DDwoR), degenerative joint disease (DJD) and subluxation (13). The primary diagnosis was established according to a set of symptoms that patients themselves noticed and for which they primarily sought treatment, while the secondary diagnosis represented a series of additional signs or pathologies observed during clinical assessment. Finally, the pooling of diagnoses was done according to the DC/TMD diagnostic criteria into i) pain disorders (TMD-P) (myalgia and arthralgia), ii) joint disorders (TMD-J) (DDwR, DDwoR, DJD and subluxation) (13).

The following data were used for analysis: demographic data including age and gender, chief complaint, presence of oral parafunctional behavior, data on the onset of symptoms during/after orthodontic treatment, spontaneous pain intensity assessed using a visual analogue scale (VAS), pain location, $\mathrm{MCO}$ and MMO, pain on palpation, existence of deflection while opening, primary and secondary diagnosis (if applicable), TMD chronicity, and finally, applied therapeutic modalities (physical therapy/ pharmacotherapy/stabilization splint).

\section{Statistical analysis}

Statistical analysis was performed using IBM SPSS Statistics for Windows, Version 26.0 (Armonk, NY: IBM Corp). The student $(\mathrm{KD})$ collected and organized the data in an Excel table as a part of a graduate thesis.

Analyses consisted of descriptive statistics and appropriate tests ( $\mathrm{t}$-test for independent/dependent samples, ANOVA and Chi-square) that were used to present significant differences between variables. A value of $p<0.05$ was considered statistically significant.
Association for the Study of Pain - IASP) koja definira akutnu bol kao bol koja traje do 3 mjeseca, a kronična bol jest bol u jednom ili više anatomskih područja koja traje ili ponavlja se dulje od 3 mjeseca te je povezana sa značajnim psihološkim stresom i/ili funkcionalnom nesposobnošću (22).

U medicinskoj dokumentaciji pacijenta zabilježen je podatak o eventualnoj ortodontskoj terapiji. Ako su se kod pacijenta pojavili novi simptomi TMP-a tijekom ortodontske terapije, ili je prekinuo terapiju zbog novih simptoma, te ako su se simptomi TMP-a pojavili neposredno nakon završetka ortodontske terapije, taj je podatak zabilježen i uzet $\mathrm{u}$ analizu.

Ako je u medicinskoj dokumentaciji bio prisutan podatak o dnevnom škripanju/ili stiskanju zubima, ili ako je postojao podatak o noćnom stiskanju/škripanju zubima koje je potvrdio ili sam pacijent ili druga osoba, taj je podatak evidentiran kao parafunkcijska oralna navika i uzet $\mathrm{u}$ analizu.

Uobičajene rendgenske snimke bile su dijagnostički vrijedne ako su na njima bile uočljive degenerativne promjene. Magnetska rezonancija (MR) TMZ-a učinjena je malobrojnim pacijentima koji nisu reagirali na terapiju ili su mogli iznimno ograničeno otvarati usta $(<30 \mathrm{~mm})$, a za koje se smatralo da je zglobnog podrijetla. Cone-beam snimke (CBCT) uzete su u obzir ako su prethodno postojale.

Moguće dijagnoze, uglavnom temeljene na kliničkim nalazima, bile su mialgija, artralgija, pomak diska s redukcijom (PDsR), pomak diska bez redukcije (PDbR), degenerativna bolest zgloba (DBZ) i subluksacija (13). Primarna dijagnoza postavljena je na temelju simptoma koje su pacijenti sami uočili i za koje su primarno tražili liječenje, a sekundarna se temeljila na nizu dodatnih znakova ili uočenih patologija na koje bi kliničari naišli tijekom kliničkog pregleda. Konačno, grupiranje dijagnoza obavljeno je prema DK/TMP dijagnostičkom kriteriju u i) bolne poremećaje (TMP-B) (mialgija i artralgija), ii) poremećaje zgloba (TMP-Z ) (PDsR, PDbR, DBZ i subluksacija) (13).

$\mathrm{Za}$ analizu je uzeto sljedeće: demografski podatci koji uključuju dob i spol, razlog dolaska, podatak o oralnim parafunkcijskim navikama, podatak o pojavi simptoma tijekom/ nakon ortodontskog liječenja, intenzitet spontane boli procijenjen vizualno analognom ljestvicom (VAS), mjesto boli, BO i MNO, bol pri palpaciji, defleksija pri otvaranju, primarna i sekundarna dijagnoza (ako je bilo primjenjivo), kronicitet TMP-a i podatak o propisanoj terapiji (fizikalna terapija/farmakoterapija/stabilizacijska udlaga).

\section{Statistička analiza}

Za statističku analizu korišten je softver IBM SPSS Statistika za Windowse, Verzija 26,0 (Armonk, NY: IBM Corp). Studentica (K. D.) prikupila je i organizirala podatke u Excel tablici kao dio svojega diplomskog rada.

Analiza podataka uključivala je deskriptivnu statistiku te primjenu odgovarajućih testova (t-test za nezavisne/zavisne uzorke, ANOVA i hi-kvadrat) koji su korišteni da bi se ispitale razlike između promatranih varijabli. Vrijednost $\mathrm{p}<0,05$ smatrana je statistički značajnom. 
The two-step cluster analysis was used as an exploratory tool intended to reveal natural groupings within the data set with selected variables. After having tested other combinations of variables, based on our clinical experience, we decided to present the grouping according to the following variables: gender, age group, presence of parafunctions, data on the onset of symptoms during/after orthodontic treatment, TMD character (acute/chronic) and primary diagnosis.

\section{Results}

The mean age was $33.88 \pm 16.66$, with a significant difference between men $(27.13 \pm 12.39)$ and women $(35.34 \pm$ 17.12) ( $\mathrm{p}<0.001)$. The distribution and mean age in each age group was as follows: i) "children and adolescents" $(\mathrm{n}=62(20.4 \%) ; 17.21 \pm 2.14$ years), ii) "middle age" $(\mathrm{n}=183$ $(60.2 \%) ; 30.52 \pm 9.06$ years), iii) older age $(\mathrm{n}=59(19.4 \%)$; $61.8 \pm 7.89$ years).

Even though there was no significant difference in the representation of women vs. men between groups ( $p=0.08)$, the most obvious difference was present in the "older age" group - from the total number of patients in the group ( $n=59)$, $89.8 \%$ were women and $10.2 \%$ were men. In the "middle age" group $82.5 \%$ were women and $17.5 \%$ men while the "children and adolescents" group consisted of $74.2 \%$ women and $25.8 \%$ men.

Regarding the reported duration of symptoms (TMD chronicity), out of 304 patients, 99 (32.6\%) were considered to be experiencing acute TMD pain and 205 (67.4\%) chronic TMD pain. A significant difference was present in acute/ chronic TMD ratios between men and women $(\chi 2=11.12$, $\mathrm{p}=0.001$ ). Women experienced chronic pain in 179 out of 250 cases (71.6\%), while the ratio for men between acute vs. chronic cases was more even $(51.9 \%$ vs. $48.1 \%$, respectively).

In $75.3 \%$ of cases $(n=229)$ patients reported that the pain was unilateral, while bilateral pain was reported by 75 patients $(24.7 \%)$. When asked to point a finger at the painful

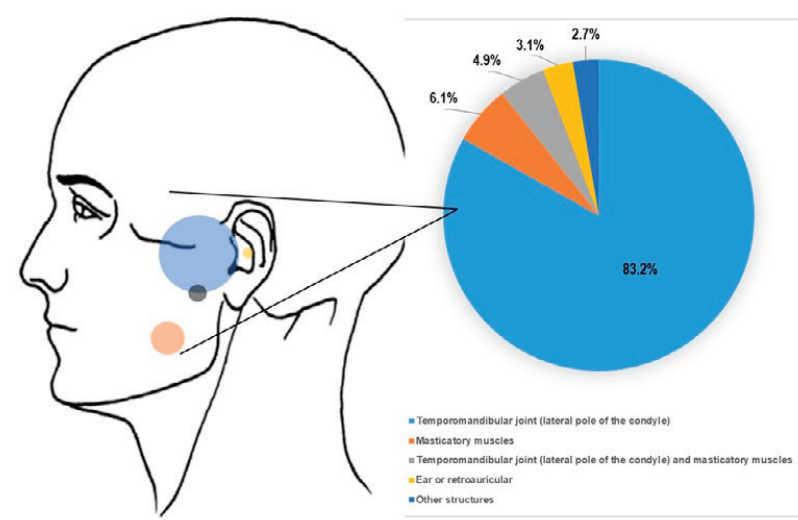

Figure 1 Distribution of reported areas that patients pointed out as painful during clinical examination* (out of $n=262$ patients)

${ }^{\star}$ Bodychart retrieved from DC/TMD Assessment Instruments

Slika 1. Distribucija bolnih područja na licu koje su pacijenti istaknuli tijekom pregleda* (od $n=262$ ) *Crtež preuzet iz Dijagnostičkog kriterija za tempromandibularne poremećaje (DK/TMP)
Klasterska analiza bila je istraživačko sredstvo namijenjeno otkrivanju prirodnih grupiranja unutar skupa podataka s odabranim varijablama. Varijable uključene u analizu bile su spol, dobna skupina, prisutnost parafunkcija, pojava simptoma tijekom/nakon ortodontskog liječenja, karakter TMP-a (akutni/kronični) i primarna dijagnoza.

\section{Rezultati}

Prosječna dob pacijenata uključenih $\mathrm{u}$ istraživanje iznosila je 33,88 $\pm 16,66$ godina, a značajno viša $(\mathrm{p}<0,001)$ zabilježena je u skupini žena $(35,34 \pm 17,12)$ u odnosu prema muškarcima $(27,13 \pm 12,39)$. Raspodjela pacijenata po dobnim skupinama bila je sljedeća: i) djeca i adolescenti (n $=62(20,4 \%) ; 17,21 \pm 2,14$ godina $)$, ii) srednja dob ( $\mathrm{n}=$ $183(60,2 \%) ; 30,52 \pm 9,06$ godina), iii) starija dob ( $\mathrm{n}=59$ $(19,4 \%) ; 61,8 \pm 7,89$ godina).

Iako u skupinama $(\mathrm{p}=0,08)$ nije bilo značajne razlike $\mathrm{u}$ zastupljenosti žena u odnosu prema muškarcima, najočitija razlika bila je u skupini starija dob. Od ukupnog broja pacijenata u toj skupini $(\mathrm{n}=59)$ njih 89,8 \% bile su žene, a 10,2 \% činili su muškarci. U skupinu srednja dob bilo je raspoređeno $82,5 \%$ žena i $17,5 \%$ muškaraca, a skupinu djeca $i$ adolescenti činilo je 74,2 \% djevojaka i 25,8 \% mladića.

Većina pacijenata patila je od kronične boli $(67,4 \%)$, pri čemu je omjer u korist kroničnih pacijenata bio značajno viši kod žena nego kod muškaraca $(\chi 2=11,12, p=0,001)$. Žene su imale kronični oblik TMP-a u 179 slučajeva od 250 (71,6 $\%$ ), a omjer između akutnih i kroničnih slučajeva kod muškaraca bio je ujednačen $(51,9 \%$, odnosno $48,1 \%)$.

U 75,3\% slučajeva $(n=229)$ pacijenti su naveli da je bol bila jednostrana, a obostranu je prijavilo njih 75 (24,7 \%). $\mathrm{Na}$ upit da prstom pokažu bolno područje (podatci dobiveni od $n=262$ pacijenta), većina je pokazala područje oko lateralnog pola TMZ-a kao primarno mjesto boli $(\mathrm{n}=218$; 83,2

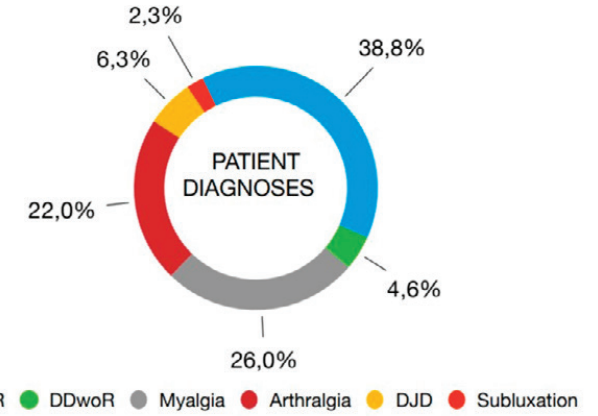

Figure 2 The frequency of TMD diagnoses. DDwR - disc displacement with reduction, DdwoR - disc displacement without reduction, DJD - degenerative joint disease

Slika 2. Učestalost TMP dijagnoza. DDwR - pomak diska s redukcijom, DdwoR - pomak diska bez redukcije, DJD - degenerativna bolest zgloba 
area (data obtained from $n=262$ patients) the majority of patients pointed solely to the area around the lateral pole of the TMJ as the primary pain location $(\mathrm{n}=218,83.2 \%)$. The distribution of reported pain areas is shown in Figure 1.

According to the data collected, the distribution of diagnoses was as follows: i) disc displacement with reduction $(\mathrm{n}=118)$; ii) disc displacement without reduction ( $\mathrm{n}=14)$; iii) myalgia $(n=79)$; iv) arthralgia $(n=67)$; v) degenerative joint disease $(n=19)$, and vi) subluxation $(n=7)$. Figure 2 shows the frequency of TMD diagnoses. Following the new DC/TMD classification of TMD, the distribution of diagnoses into TMD-P and TMD-J groups was as follows: TMD-P 48\% and TMD-J 52\%. A significant difference between the number of patients with TMD-P or TMD-J concerning TMD chronicity was found $(\chi 2=4.29, \mathrm{p}=0.038)$. In both groups, there were more chronic than acute patients with significantly more chronic patients in the TMD-J group when compared to the TMD-P group (72.8\% vs. 61.6\%).

In 55 patients, a secondary diagnosis was identified. The most common secondary diagnosis was myalgia (41\%) followed by arthralgia (28.2\%), disc displacement with reduction (9\%), degenerative joint disease $(9 \%)$, subluxation $(11 \%)$, and disc displacement without reduction (1.8\%).

Data on parafunctional behavior were confirmed in 44 patients (14.5\%). In the rest of the patients $(85.5 \%)$, the data on the existence of parafunctional behavior could not be supported by sufficient information regarding grinding, clenching, or other parafunctional oral behavioral habits. Of the total 44 of patients who reported the existence of parafunctional behavior, $29.5 \%$ of them experienced activities during waking hours, $41 \%$ activities during sleep, and $29.5 \%$ both.

In medical history, orthodontic therapy had been recorded in 71 patients. Data on the onset of symptoms during/just after orthodontic treatment was found in the medical history of 44 patients, $14.5 \%$ out of all patients ( $n=304)$, and $61.97 \%$ out of patients with orthodontic treatment in their medical history $(\mathrm{n}=71)$. Out of those 44 patients, $77.3 \%$ had chronic and $22.7 \%$ had acute TMD. In the group "children and adolescents" a significantly higher number of patients $(\chi 2=10.54 ; p=0.001)$ with the onset of symptoms during/ just after orthodontic treatment was found when compared to adult patients (pooled "middle age" and "older age") (27.4\% vs. $11.2 \%)$.

The data regarding quantification of spontaneous pain, assessed with VAS, was present in 87 patients with a mean of $6.14 \pm 1.79$ with no significant difference with respect to gender $(\mathrm{p}=0.32)$, however, VAS was observed to be lower in men $(5.38 \pm 1.71)$ than in women $(6.27 \pm 1.79)$. When VAS was evaluated according to age groups, the highest values were observed in the "older age" group $(7.43$ (95\% CI 6.658.20)), followed by 6.19 (95\% CI 5.55-6.83) in the "children and adolescence" group, and the lowest in the "middle age" group (5.77 (95\% CI 5.24-6.30)). No significant difference in pain intensity between acute and chronic TMD patients was found (mean VAS for acute TMD: $5.84 \pm 1.55$, mean VAS for chronic TMD: $6.30 \pm 1.91 ; \mathrm{p}=0.1$ ).

The data regarding the confirmation of familiar pain on muscle palpation were present in medical records of 104
\%). Prikaz područja koja su pacijenti tijekom anamnestičkog protokola isticali kao bolna nalazi se na slici 1 .

Prema prikupljenim podatcima raspodjela dijagnoza bila je sljedeća: i) pomak diska s redukcijom $(\mathrm{n}=118)$; ii) pomak diska bez redukcije $(\mathrm{n}=14)$; iii) mialgija $(\mathrm{n}=79)$; iv) artralgija $(n=67)$; v) degenerativna bolest zglobova $(n=19)$; vi) subluksacija $(\mathrm{n}=7)$.

Učestalost dijagnoza TMP-a prikazana je na slici $2 . S$ obzirom na novu klasifikaciju dijagnoza DK/TMP-a, bolni poremećaji (TMP-B) bili su prisutni u $48 \%$ slučajeva, a poremećaji zgloba (TMP-Z) u $52 \%$. U objema skupinama bilo je više kroničnih nego akutnih oblika TMP-a sa značajno više kroničnih pacijenata u skupini TMP-Z u usporedbi sa skupinom TMP-B $(72,8 \%$ prema $61,6 \%)(\chi 2=4,29, \mathrm{p}=0,038)$.

$\mathrm{Za} 55$ pacijenata bilo je moguće postaviti sekundarnu dijagnozu. Najčešća je bila mialgija (41 \%), a slijede artralgija $(28,2 \%)$, pomak diska s redukcijom (9\%), degenerativna bolest zgloba $(9 \%)$, subluksacija (11\%) i pomak diska bez redukcije $(1,8 \%)$.

Podatak o oralnim parafunkcijskim navikama evidentiran je kod 44 pacijenta (14,5\%), a u medicinskoj dokumentaciji ostalih $(85,5 \%)$ nije bilo informacija na temelju kojih bi se mogla potvrditi pojava stiskanja i/ili škripanja zubima ili drugih oralnih navika. Od ukupno 44 pacijenta koji su prijavili parafunkcijske navike, njih $29,5 \%$ prijavilo je dnevne parafunkcijske aktivnosti, $41 \%$ noćne, a 29,5\% i dnevne i noćne.

U medicinskoj dokumentaciji kod 71 pacijenta zabilježen je podatak o već završenoj ili trenutačnoj ortodontskoj terapiji. Podatak o simptomima tijekom/neposredno nakon ortodontske terapije zabilježen je kod 44 pacijenta, što je činilo $14,5 \%$ od ukupno uključenih pacijenata $(\mathrm{n}=304)$, odnosno $61,97 \%$ pacijenata sa zabilježenim ortodontskim liječenjem u medicinskoj dokumentaciji $(\mathrm{n}=71)$. Od navedena 44 pacijenta, 77,3 \% imalo je kronični TMP, a 22,7 \% akutni. U skupini djeca $i$ adolescenti utvrđen je značajno veći broj pacijenata $(\chi 2=10,54 ; p=0,001)$ kod kojih je postojao podatak o pojavi simptoma tijekom/neposredno nakon ortodontske terapije u usporedbi s odraslim pacijentima (zajedno srednja dob i starija dob) (27,4\% prema 11,2\%).

Podatak o intenzitetu spontane boli, koju su pacijenti procjenjivali s pomoću VAS ljestvice, bio je zabilježen za 87 pacijenata, pri čemu je bol iznosila prosječno $6,14 \pm 1,79$, bez značajne razlike s obzirom na spol $(\mathrm{p}=0,32)$. No niži intenzitet boli uočen je kod muškaraca $(5,38 \pm 1,71)$ u usporedbi sa ženama $(6,27 \pm 1,79)$. Ako se promatra usporedba prema dobnim skupinama, najviše VAS vrijednosti zabilježene su u skupini starija dob [7,43 (95 \% CI 6,65 - 8,20)], nakon čega slijedi skupina djeca $i$ adolescenti s prosječnim iznosom VAS-a od 6,19 (95\% CI 5,55 - 6.83), a najniže zabilježene su u skupini srednja dob [5,77 (95 \% CI 5,24-6,30]. Nisu pronađene značajne razlike u intenzitetu spontane boli između akutnih i kroničnih pacijenata s TMP-om (srednji VAS za akutni TMP: 5,84 $\pm 1,55$, srednji VAS za kronični TMP: $6,30 \pm 1,91 ; p=0,1)$.

Za 104 pacijenta (34,2 \%) bilo je zabilježeno da je palpacija žvačnih mišića izazivala pojavu poznate boli, a za 140 $(41,6 \%)$ evidentiran je podatak da je palpacija TMZ-a pota- 
patients $(34.2 \%)$, while in medical records of 140 patients $(41.6 \%)$ the data regarding the confirmation of familiar pain during TMJ palpation existed. Data regarding the presence of uncorrected deviation (deflection) during the opening were recorded in 76 patients (25\%). In 179 patients (58.9\%), a limited mouth opening was noted during the clinical examination, while the report of pain during opening was present in 166 patients (54.6\%). Limited mouth opening was present in all participants with disc displacement without reduction (100\%), 76.1\% participants with arthralgia, 44.9\% participants with disc displacement with reduction, $58.2 \%$ participants with myalgia, and $57.9 \%$ participants with degenerative joint disease. The frequency of limited mouth opening in the TMD-P and TMD-J groups was $66.4 \%$ vs. $51.9 \%(\chi 2=6.63, \mathrm{p}=0.01)$.

The mean MCO was $35.14 \pm 10 \mathrm{~mm}$ (data obtained from 296 patients), while the mean $\mathrm{MMO}$ was $39.51 \pm 8.63 \mathrm{~mm}$ (data obtained from 166 patients).

As a therapeutic modality, physical therapy was prescribed in 171 cases (56.3\%), occlusal splint in 123 cases (40.5\%), and pharmacotherapy in 59 cases (19.4\%) (Note: one patient might have more than one therapeutic modality). Pharmacotherapy and occlusal splints were predominantly prescribed for patients with TMD-P when compared to TMD-J (pharmacotherapy: $61 \%$ vs. $39 \%, \chi 2=5.09, \mathrm{p}=0.02$; occlusal splint: $56.1 \%$ vs. $43.9 \%, \chi 2=5.39, \mathrm{p}=0.02$ ).

The data on MRI imaging were recorded in 7 patients, out of which the anterior disc displacement without reduction was confirmed in 4 patients, in 2 patients the diagnosis was subluxation, while in 1 patient joint hypomobility was present.

\section{Grouping of the patients}

Two-step cluster analysis with selected variables revealed 5 clusters (Table 1 ).

Data presented in Table 1 revealed the natural groupings of participants. Cluster No. 1 is characterized by a high prevalence of children/adolescents, chronic TMD, mainly DDwR and a high prevalence of the onset of symptoms during/just after orthodontic treatment. Cluster No. 2 consisted mainly of chronic middle-aged patients with no parafunctional behavior, no orthodontic treatment in patient's history and DDwR as the most common primary diagnosis. Cluster No. 3 mainly included middle-aged and older patients with the presence of parafunctional behavior, with almost equal representation of acute and chronic cases, as well as the equal representation of two diagnoses, DDwR and myalgia. Cluster No. 4 was mainly composed of older women with chronic TMD and the highest prevalence of DJD. Middle-aged patients with a high prevalence of acute TMD and myalgia mostly comprised cluster No. 5 .

\section{Discussion}

Signs and symptoms of TMD are present in all age groups. However, the peak incidence is considered to be between the ages of 20 and 40, which is in line with the data obtained in this study (23). Although it is traditionally believed that TMD in women most commonly occurs in their knula poznatu bol. Podatak o defleksiji pri otvaranju usta bio je zabilježen kod 76 pacijenata $(25 \%)$, kod njih 179 (58,9 $\%)$ tijekom pregleda zabilježeno je ograničeno otvaranje usta, a podatak o boli pri otvaranju bio je zabilježen kod $166 \mathrm{pa}-$ cijenata $(54,6 \%)$. Ograničeno otvaranje usta uočeno je kod svih pacijenata s pomakom diska bez redukcije (100\%), 76,1 $\%$ pacijenata $s$ artralgijom, $44,9 \%$ pacijenata s pomakom diska s redukcijom, 58,2 \% pacijenata s mialgijom i 57,9\% pacijenata s degenerativnom bolešću zgloba. Učestalost ograničenog otvaranja usta u skupini TMP-B i skupini TMP-Z iznosila je 66,4 \% prema 51,9\% $(\chi 2=6,63, \mathrm{p}=0,01)$.

Prosječno otvaranje usta bez boli (BO) iznosilo je 35,14 $\pm 10 \mathrm{~mm}$ (podatak zabilježen za 296 pacijenata), a prosječno maksimalno neasistirano otvaranje usta (MNO) iznosilo je 39,51 $\pm 8,63 \mathrm{~mm}$ (podatak zabilježen za 166 pacijenata).

Fizikalna terapija propisana je u 171 slučaju (56,3\%), okluzijska udlaga u 123 slučaja $(40,5 \%)$, a farmakoterapija u 59 slučajeva (19,4\%) (napomena: jedan pacijent mogao je dobiti više vrsta terapije). Farmakoterapija i okluzijska udlaga češce su propisivane pacijentima u skupini TMP-B u usporedbi sa skupinom TMP-Z (farmakoterapija: $61 \%$ prema $39 \%, \chi^{2}=5,09, \mathrm{p}=0,02$; okluzijska udlaga: $56,1 \%$ prema $\left.43,9 \%, \chi^{2}=5,39 \mathrm{p}=0,02\right)$.

Sedam pacijenata poslano je na magnetsku rezonanciju, pri čemu je za 4 potvrđen prednji pomak diska bez redukcije, za 2 je zabilježena subluksacija, a kod jednoga je nalaz potvrdio hipomobilnost zgloba.

\section{Grupiranje pacijenata}

S pomoću dvostupanjske klasterske analize $s$ odabranim varijablama dobiveno je 5 klastera (tablica 1).

Podatci u tablici 1 pokazuju prirodno grupiranje sudionika. Obilježja klastera br. 1 visoka su prevalencija djece/ adolescenata, kronični TMP, uglavnom PDsR i visoka zastupljenost simptoma tijekom/nakon ortodontskog liječenja. Klaster br. 2 sastojao se uglavnom od pacijenata srednje dobi s kroničnim oblikom TMP-a, bez parafunkcijskih oralnih navika u anamnezi i PDsR-om kao najčešćom primarnom dijagnozom. Klaster br. 3 uglavnom je obuhvaćao pacijente srednje i starije dobi s prisutnošću parafunkcijskih navika i gotovo jednakom zastupljenošću akutnih i kroničnih slučajeva, te jednakom zastupljenošću dviju dijagnoza - PDsRom i mialgijom. Klaster br. 4 uglavnom su činile starije žene s kroničnim TMP-om i najvećom prevalencijom DBZ-a. Klaster br. 5 činili su uglavnom pacijenti iz skupine srednja dob, $s$ akutnim TMP-om i mialgijom kao najčešćom dijagnozom.

\section{Rasprava}

Znakovi i simptomi TMP-a pojavljuju se u svim dobnim skupinama. No smatra se da je najveća incidencija između 20. i 40. godine, što je u skladu s podatcima dobivenima u ovom istraživanju (23). Iako se tradicionalno smatra da se TMP kod žena najčešće pojavljuje u reproduktivnim godi- 
Table 1 Percentages for each category within variables in each cluster

Tablica 1. Postotni udjeli kategorija unutar varijabli u svakom od klastera

\begin{tabular}{|c|c|c|c|c|c|c|}
\hline \multirow[b]{2}{*}{ Variables $\bullet$ Varijable } & \multirow[b]{2}{*}{ Categories • Kategorije (\%) } & \multicolumn{5}{|c|}{ Clusters • Klasteri } \\
\hline & & $\stackrel{1}{1}$ & $\stackrel{2}{2}$ & $(n=42)$ & $\stackrel{4}{4}(n=45)$ & $\left(\begin{array}{c}5 \\
n=59)\end{array}\right.$ \\
\hline \multirow{2}{*}{ Gender $\bullet$ Spol } & Men $•$ Muškarci & 22.4 & 11 & 23.8 & 2.2 & 30.5 \\
\hline & Women $\bullet$ Žene & 77.6 & 89 & 76.2 & 97.8 & 69.5 \\
\hline \multirow{3}{*}{ Age group $\bullet$ Dobna skupina } & $\begin{array}{l}\text { Children and adolescents } \bullet \text { Djeca } \\
\text { i adolescenti }\end{array}$ & 59.7 & 0 & 8 & 0 & 26.8 \\
\hline & Middle age $\bullet$ Srednja životna dob & 38.3 & 98 & 59.5 & 0 & 71.2 \\
\hline & Older age $\bullet$ Starija životna dob & 2 & 2 & 32.5 & 100 & 2 \\
\hline \multirow{2}{*}{ Parafunctional behavior $\bullet$ Parafunkcijske navike } & Yes $\bullet \mathrm{Da}$ & 3 & 0 & 100 & 0 & 0 \\
\hline & $\mathrm{No} \cdot \mathrm{Ne}$ & 97 & 100 & 0 & 100 & 100 \\
\hline \multirow{2}{*}{$\begin{array}{l}\text { Occurrence of symptoms during/after } \\
\text { orthodontic therapy } \bullet \text { Pojava simptoma tijekom/ } \\
\text { nakon ortodontske terapije }\end{array}$} & Yes $\bullet \mathrm{Da}$ & 65.7 & 0 & 0 & 0 & 0 \\
\hline & $\mathrm{No} \bullet \mathrm{Ne}$ & 34.3 & 100 & 100 & 100 & 100 \\
\hline \multirow{2}{*}{ TMD duration $\bullet$ Trajanje TMP-a } & Acute $\bullet$ Akutno & 14.9 & 0 & 40.5 & 28.9 & 100 \\
\hline & Chronic $\bullet$ Kronično & 85.1 & 100 & 59.5 & 71.1 & 0 \\
\hline \multirow{6}{*}{ Primary diagnosis $\bullet$ Primarna dijagnoza } & DDwR・PDsR & 49.3 & 47.3 & 38.1 & 13.4 & 32.2 \\
\hline & DDwoR $・ P D b R$ & 4.4 & 5.5 & 0 & 2.2 & 5.1 \\
\hline & Myalgia $\bullet$ Mialgija & 25.4 & 19.8 & 38.1 & 24.4 & 33.9 \\
\hline & Arthralgia $\bullet$ Artralgija & 16.4 & 22 & 19 & 26.7 & 27.1 \\
\hline & $\mathrm{DJD} \cdot \mathrm{DBZ}$ & 1.5 & 2.1 & 0 & 33.3 & 1.7 \\
\hline & Subluxation $\bullet$ Subluksacija & 3 & 3.3 & 4.8 & 0 & 0 \\
\hline
\end{tabular}

$\mathrm{n}$ - number of participants in each cluster; DDwR - Disc displacement with reduction; DDwoR - Disc displacement without reduction/ n-broj ispitanika u pojedinom klasteru; PDsR - pomak diska s redukcijom; PDbR - pomak diska bez redukcije; DBZ - degenerativna bolest zgloba

reproductive years (20-40), recent studies have shown that the incidence of TMD in women is more common between the ages of 45 and 65 which could explain our results with men being significantly younger than women $(24,25)$. Such data can be supported by the fact that more women reported TMD than men in the "older age" group (26).

The significant difference in the incidence and progression of TMD with respect to gender probably stems from the interaction of various behavioral, hormonal, anatomi$\mathrm{cal}$, and psychosocial factors (27). The prevalence of TMD in our clinical setting of 4.6:1, in favor of women, is consistent with current epidemiological information on the presence of TMD recorded in clinical studies (28). Such a disparity is often explained, not only as a physiological difference between the sexes but also as a consequence of women's greater concern for their own health and their more frequent demand for health care (29). There were significantly more women with chronic TMD than acute, compared to men where the ratio between acute and chronic forms was approximately 1:1, which is in line with a study by Carlsson et al. where the signs and symptoms of TMD were more intense and prolonged in women (30).

The two most common diagnoses were disc displacement with reduction and myalgia, a result that is commonly obtained in other studies $(31,32)$. In patients with disc displacement with reduction, the presence of "clicking" during function can create discomfort and occasional worry. Such patients, in a large number of cases, have no other symptoms, and their condition is generally not an indication for therapy. Their concerns are most often relieved through conversation and education about the condition affecting the tem- nama $(20-40)$, nedavna istraživanja pokazala su da je učestalost TMP-a kod žena ipak češća u dobi između 45 i 65 godina, što bi moglo objasniti rezultate ovog istraživanja u kojemu su muškarci bili znatno mlađi od žena $(24,25)$. Takvi podatci mogu se potkrijepiti činjenicom da u skupini starija dob žene prijavljuju TMP češće nego muškarci (26). Značajna razlika u učestalosti i napredovanju TMP-a s obzirom na spol vjerojatno proizlazi iz složenoga međudjelovanja različitih bihevioralnih, hormonskih, anatomskih i psihosocijalnih čimbenika (27). Prevalencija TMP-a u našem istraživanju iznosi 4,6:1, u korist žena i u skladu je s trenutačnim epidemiološkim podatcima zabilježenima u kliničkim studijama (28). Takva se nejednakost često objašnjava ne samo kao fiziološka razlika među spolovima, nego i kao posljedica veće brige žena za vlastito zdravlje i njihove češće potražnje za zdravstvenom skrbi (29). U skupini žena bilo je znatno više ispitanica s kroničnim oblikom TMP-a nego s akutnim, u usporedbi s muškarcima kod kojih je omjer akutnih i kroničnih oblika bio približno $1: 1$. To je u skladu s istraživanjem Carlssona i suradnika koji navode da su znakovi i simptomi TMP-a kod žena intenzivniji i dugotrajniji (30).

Dvije najččsce dijagnoze su pomak diska $s$ redukcijom i mialgija, a sličan rezultat nalazimo i u drugim studijama (31, 32). Kod pacijenata s pomakom diska s redukcijom, pojava škljocanja tijekom funkcije može stvoriti nelagodu i povremenu zabrinutost. Takvi pacijenti najčěšće nemaju drugih simptoma, a njihovo stanje uglavnom nije indikacija za provođenje terapije. Zabrinutost zbog škljocanja najčešće se rješava razgovorom i edukacijom o stanju koje utječe na TMZ. Dijagnoze, koje slijede prema učestalosti, uglavnom su bolne, što ne iznenađuje s obzirom na to da bol ometa normalno 
poromandibular joint. Diagnoses, which follow in frequency, were mostly painful diagnoses. This result was not surprising since pain impedes the normal functioning of patients. A great number of patients consider pain the most limiting symptom and alarm for seeking professional help (26).

The association between orthodontic therapy and the occurrence of signs and symptoms of TMD during or after therapy is still the subject of debate in dental community (33). Nevertheless, the results of studies have confirmed for years that orthodontics is not the primary cause of TMD (34). At our clinic, we noticed a frequent occurrence of TMD symptoms during orthodontic therapy, especially during the use of an intermaxillary rubber train or bimaxillary removable appliances. As occlusion and oral parafunctional habits are considered a risk factor in hypervigilant patients, it is possible that changing the position of the lower jaw over time may cause painful problems in sensitive (hypervigilant) patients. Nowadays, orthodontic therapy is equally present in children and adults, and consequently, the average age of patients with orthodontic therapy has changed. Middle age is a higher risk factor for TMD, which may consequently affect the frequent overlap of TMD symptoms and the implementation of active orthodontic therapy. This may lead the clinician to think that a cause-and-effect relationship between TMD and orthodontic therapy exists when in fact there is a chance that there is no connection between the two $(33,35)$.

Although the literature states that the prevalence of pain in the temporomandibular area with respect to age is highest around middle age, the results of this study have revealed that higher values of VAS were observed in the older group of patients (35). Our results can be explained by the fact that older patients are likely to have more free time to think about pain compared to younger ones. On the other hand, the prevalence of orofacial pain peaks around age 65 , which coincides with the age of the subjects in this study, and it is precisely this kind of pain that can be presented as a painful diagnosis of TMD (36).

Despite the lack of consensus on the efficacy and, in general, the necessity of using an occlusal splint, the treatment of TMD often begins with the development of a stabilization splint (37). However, experts in the field of diagnostics and treatment of TMD recommend physical therapy, i.e. a manual musculoskeletal approach as the first choice in treatment, which was the guiding thought of our experts (38). Physical therapy has been shown to be successful in treating both muscular and joint disorders, primarily in increasing mouth opening (39). In addition to simplicity and cost, its advantage is the improvement of signs and symptoms of TMD after only a short period of time, which allows a quick assessment of the need for further therapy (40). Additional advantages of physical therapy are that it is not limited in time and, if performed correctly, there are no harmful effects. Therefore, the patient can start and stop physical therapy whenever he/she feels the need for it. Although there is no uniform evidence and accurate knowledge of the mechanisms of action, a large number of studies indicate the existence of a significant difference between the occlusal splint and other placebo forms, with occlusal splint performing sig- funkcioniranje pacijenata. Za pacijente bol je najveći ograničavajući simptom te povod za traženje stručne pomoći (26).

Povezanost između ortodontske terapije i pojave znakova i simptoma TMP-a tijekom terapije ili nakon nje i dalje je predmet mnogih rasprava (33). Ipak, rezultati studija već godinama potvrđuju da ortodoncija nije primarni uzrok TMPa (34). U našoj klinici zapazili smo učestalu pojavu simptoma TMP-a tijekom ortodontske terapije, posebno pri uporabi intermaksilarnoga gumenog vlaka ili bimaksilarnih mobilnih uređaja. Budući da se okluzija i oralne parafunkcijske navike smatraju rizičnim čimbenicima kod hipervigilantnih pacijenata, možda promjena položaja donje čljusti tijekom vremena izazove bolne probleme kod onih osjetljivih. $S$ druge strane, danas je ortodontska terapija podjednako prisutna i kod djece i kod odraslih, pa se posljedično promijenila i prosječna dob pacijenata na ortodontskoj terapiji. Srednja dob je rizični čimbenik za TMP, a upravo taj podatak može objasniti učestalo preklapanje simptoma TMP-a i aktivne ortodontske terapije. To može navesti kliničara da pomisli kako postoji uzročno-posljedična veza između TMP-a i ortodontske terapije kada zapravo postoji mogućnost da između njih nema povezanosti $(33,35)$.

Iako se u literaturi navodi da je prevalencija boli povezane s TMP-om najveća u srednjoj dobi, u ovoj su studiji više vrijednosti VAS-a zabilježene u skupini pacijenata starije dobi (35). Takav rezultat možda možemo objasniti činjenicom kako je vjerojatnije da će stariji pacijenti imati više slobodnog vremena za razmišljanje o boli. $S$ druge strane, prevalencija drugih oblika orofacijalne boli doseže vrhunac oko 65. godine, što se podudara s dobi pacijenata s najvišim VAS-om u ovom istraživanju, a upravo se takva bol katkad može zamijeniti s TMP-om (36).

Unatoč nedostatku konsenzusa o učinkovitosti i, općenito, o potrebi korištenja okluzijske udlage, liječenje TMP-a često počinje izradom stabilizacijske udlage (37). Stručnjaci u području dijagnostike i liječenja TMP-a preporučuju fizikalnu terapiju kao prvi izbor u liječenju, što je misao vodilja i naših stručnjaka (38). Pokazalo se da je fizikalna terapija uspješna u liječenju poremećaja mišića i zglobova, u prvom redu u povećanju opsega otvaranja usta (39). Uz jednostavnost provođenja i nisku cijenu, prednost fizikalne terapije jest i to što, ako je izbor pravilan, poboljšanje znakova i simptoma TMP-a pojavljuje se vrlo brzo, što omogućuje brzu procjenu potrebe za drukčijim protokolom liječenja (40). Dodatna prednost fizikalne terapije jest to što se može primijeniti bez vremenskog ograničenja i ako se pravilno izvodi, nema štetnih posljedica. Pacijent može sam početi i prestati s terapijom kad god za to osjeća potrebu. Iako ne postoje jedinstveni dokazi o mehanizmima djelovanja, u mnogim studijama autori upozoravaju na značajnu razliku između učinkovitosti stabilizacijske udlage i ostalih placebo oblika udlaga. Stabilizacijska udlaga učinkovitija je u smanjenju boli i ograničenja u usporedbi s udlagama koje ne obuhvaćaju žvačne plohe zuba i tankim folijama (41). U kliničkoj praksi, kao što sugerira najnovija literatura, okluzijska udlaga treba se koristiti u kombinaciji s fizikalnom i bihevioralnom terapijom, jer njezin samostalni doprinos ublažavanju boli još nije u cijelosti razjašnjen (40). Naši rezultati po- 
nificantly better in terms of reducing pain and limitations when compared to non-occluding devices and thin foils (41). In clinical practice, as the newest literature suggests, splints should be used in combination with physical and behavioral therapy since its precise contribution to pain-relief has not been fully understood (40). Our results showed that splints are prescribed more to patients with chronic forms of TMD.

The efficacy of pharmacotherapy in the treatment of chronic pain in TMD has not been supported by solid scientific evidence (42). Given that drugs used in TMD pharmacotherapy such as non-steroid anti-inflammatory drugs (NSAIDs) and benzodiazepines have adverse side effects, the risk-benefit ratio in each individual situation should be assessed carefully (43). Although NSAIDs and benzodiazepines are recommended for short-term pain control in patients with TMD, long-term pharmacotherapy should be considered in those patients who have a poorer response to therapy (44). It is important to emphasize that we used additional diagnostic methods, such as magnetic resonance imaging, in a small number of cases that did not respond to therapy, in accordance with modern guidelines for the diagnosis and treatment of TMD (45). Namely, it is important to make additional imaging if the findings might affect the current or future therapeutic direction.

By performing cluster analysis, we were able to show the natural grouping of patients and create a pattern in which it is possible to easily classify new patients and align different therapeutic options with the group profile. For example, in patients constituting cluster number 5 (mostly acute and pain patients), it would be best to assess, among other things, the level of stress, given that stress is often associated with exacerbation of painful conditions and begin taking a behavioral approach (46). With such acute forms, it would be best to limit the function to a comfortable opening and avoid anything that exacerbates the discomfort. In patients with severe, limiting pain, we would also implement pharmacotherapy over a shorter period of time. When the pain begins to subside, the patient should slowly start doing exercises. In such patients, it is important to start therapy as soon as possible in order to prevent progression to a chronic condition, especially if those patients exhibit anxiety and/or depressive traits in addition to high self-perceived pain $(46,47)$.

This study has certain limitations. One of them is lack of certain data (for example, data on pain intensity according to VAS was recorded in a smaller number of patients), but such a lack is not significant if we consider the number of processed medical records and a generally large number of subjects and uniform approach to diagnosis and treatment of clinicians whose patients have been taken for analysis. In addition, there might be a bias in selecting variables for cluster analysis. However, we used a two-stage cluster analysis in which finishing optimizes homogeneity within the cluster and heterogeneity between clusters and is thus less susceptible to external factors (48). Also, the patient profile is related only to the specified institution and it is advisable to interpret the data with caution. kazuju da se okluzijska udlaga češće propisuje pacijentima s kroničnim oblicima TMP-a.

Učinkovitost farmakoterapije u liječenju kronične boli u slučaju TMP-a nije potkrijepljena čvrstim znanstvenim dokazima (42). S obzirom na to da lijekovi koji se koriste za ublažavanje TMP-a, poput nesteroidnih protuupalnih lijekova (NSAR) i benzodiazepina, imaju nuspojave, za svakog pacijenta uvijek treba procijeniti rizik i korist (43). Iako se NSAR i benzodiazepini preporučuju za kratkotrajnu kontrolu boli kod pacijenata s TMP-om, dugotrajna upotreba lijekova može doći u obzir za one koji slabije odgovaraju na terapiju (44). Važno je istaknuti da, u skladu sa suvremenim smjernicama za dijagnozu i liječenje TMP-a, u malom broju slučajeva ako pacijenti ne reagiraju na terapiju, koristimo se dodatnim dijagnostičkim metodama, poput magnetske rezonancije (45). Naime, dodatne snimke indicirane su samo u slučaju kada bi dijagnoza koja se otkrije na snimci promijenila ili utjecala na daljnji protokol liječenja.

Primjenom klasterske analize uspjeli smo prezentirati prirodno grupiranje pacijenata i stvoriti uzorak s pomoću kojega je moguće jednostavno klasificirati nove pacijente i uskladiti terapijske mogućnosti s profilima homogenih skupina. Na primjer, kod pacijenata koji čine klaster broj 5 (uglavnom akutni i pacijenti s bolovima), preporuka je procijeniti razinu stresa s obzirom na to da je stres često povezan $s$ pogoršanjem bolnih stanja te početi s bihevioralnim pristupom (46). U slučaju takvih akutnih oblika najbolje bi bilo ograničiti funkciju na ugodno otvaranje i izbjeći sve što povećava nelagodu. Ako pacijent osjeća jaku, ograničavajuću bol, preporuka je tijekom kraćeg razdoblja uzimati lijekove za ublažavanje boli, a nakon toga primijeniti vježbe. Kod takvih slučajeva važno je početi s terapijom što je prije moguće da bi se spriječilo napredovanje u kronično stanje, posebno ako pacijent, uz visoku razinu boli, pokazuje visoku razinu anksioznosti i/ili depresije $(46,47)$.

Ovo istraživanje ima određena ograničenja. Jedno od njih je nedostatak određenih podataka (na primjer, podatak o jakosti boli prema VAS-u zabilježen je kod manjeg broja pacijenata), no takav nedostatak nije toliko značajan kada se uzme u obzir broj obrađenih medicinskih kartona i općenito velik broj ispitanika te usklađen pristup kliničara u dijagnozi i liječenju. Uz to, moguća je pristranost u odabiru varijabli za klastersku analizu, no koristili smo se dvostupanjskom klasterskom analizom čija završna obrada optimizira između homogenosti unutar klastera i heterogenosti između klastera te je manje osjetljiva na vanjske čimbenike (48). Također, $s$ obzirom na to da su bili uključeni samo pacijenti koji su se liječili u navedenoj instituciji, preporučuje se podatke tumačiti s oprezom. 


\section{Conclusions}

Our results are largely in accordance with current epidemiological knowledge on TMD. Women predominated in all age groups and most of the patients experienced chronic pain. Classification of patients into homogeneous groups using the clustering method could provide better identification of subgroups of conditions that mainly occur together in these patients, thus providing a clue for a better prognosis of TMD patients.

\section{Acknowledgements}

This study has been fully supported by the Croatian Science Foundation Project "Genetic polymorphisms and their association with temporomandibular disorders" (No.IP2019-04-6211) and 'Young Researchers' Career Development Project - Training of Doctoral Students".

\section{Conflict of interest}

\section{None declared.}

Author's contribution: E. V. - contributed to study design, data analysis, interpretation and visualization, manuscript writing and editing; K. D. - contributed to the data collection and visualization, manuscript writing and editing; M. Z. - contributed to the manuscript writing, editing and revision; I. Z. A. - contributed to the conceptualization of the study and study design, data analysis and interpretation, manuscript writing, editing and critically revising of the manuscript before submission.

\section{Zaključci}

Rezultati ove studije u skladu su s postojećim spoznajama o epidemiologiji TMP-a. U svim dobnim skupinama prevladavale su žene, a većina pacijenata isticala je kroničnu bol. Razvrstavanje pacijenata u homogene skupine primjenom metode grupiranja moglo bi pomoći boljem prepoznavanju podskupina stanja koja se kod pacijenata s TMP-om uglavnom pojavljuju zajedno, te na taj način pružiti osnovu za precizniji pristup u njihovu zbrinjavanju.

\section{Potpora}

Ovaj rad podupire projekt Hrvatske zaklade za znanost Povezanost genskih polimorfzama s temporomandibularnim poremé́ajima (IP-2019-04-6211) i Projekt razvoja karijere mladih istraživača - izobrazba novih doktora znanosti (DOK2020-01).

\section{Sukob interesa}

Nije bilo sukoba interesa.

Doprinos autora: E. V. - je doprinijela dizajnu studije, analizi podataka te njihovoj interpretaciji i vizualizaciji, pisanju i uređivanju teksta; K.D. - je doprinijela prikupljanju podataka te njihovoj vizualizaciji, pisanju i uređivanju teksta; M. Z. - je doprinio pisanju, uređivanju i reviziji teksta; I. Z. A. - je doprinijela konceptualizaciji i dizajnu studije, analizi i interpretaciji podataka, pisanju i kritičkom pregledu teksta prije predaje.

\section{Sažetak}

Svrha rada: Cilj ovog istraživanja bio je procijeniti tipične i najčešće karakteristike pacijenata koji boluju od temporomandibularnih poremećaja (TMP) analizom njihove medicinske dokumentacije. Materijali i metode: Iz medicinske dokumentacije 304 pacijenta S TMP-om (250 žena i 54 muškarca) koji su bili upućeni u Kliniku za stomatologiju Kliničkoga bolničkog centra Zagreb od listopada 2016. do listopada 2020. godine zbog temporomandibularne boli, prikupljeni su demografski podatci te podatci o obilježjima TMP-a. Za potrebe analize formirane su tri dobne skupine: djeca i adolescenti (do 19 godina), srednja dob (od 20 do 50 godina), starija dob ( $>50$ godina). Klasterska analiza provedena je da bi se bolesnici s TMP-om svrstali u homogene skupine. Rezultati: Prosječna dob pacijenata čiji su podatci uključeni u istraživanje iznosila je $33,8 \pm 16,66$ godina, a značajno viša zabilježena je u skupini žena $(p<0,001)$. Većina pacijenata patila je od kronične boli $(67,4 \%)$, pri čemu je omjer u korist kroničnih pacijenata bio znatno veći kod žena nego kod muškaraca $(p=0,001)$. Podatak o parafunkcijskim navikama mogao se potvrditi kod $14,5 \%$ pacijenata. Podatci o pojavi simptoma tijekom/neposredno nakon ortodontskog liječenja bili su zabilježeni za $14,5 \%$ pacijenata. Podatak 0 intenzitetu spontane boli, mjerene vizualno analognom ljestvicom, bio je zabilježen za 87 pacijenata, pri čemu je prosječna bol iznosila $6,14 \pm 1,79$, a najviše su vrijednosti zabilježene u skupini starije dobi. Fizikalna terapija bila je najčešće primjenjivana (56,3\%), a slijedila je okluzijska udlaga (40,5 \%). Klasterska analiza otkrila je pet različitih homogenih skupina koje se grupiraju prema promatranim varijablama. Zaključci: Rezultati ove studije u skladu su s dosadašnjim spoznajama o epidemiologiji TMP-a. U svim dobnim skupinama prevladavale su žene, a većina pacijenata osjećala je kroničnu bol. Razvrstavanje u homogene skupine primjenom metode grupiranja moglo bi pomoći boljem prepoznavanju podskupina stanja koja se kod pacijenata s TMP-om uglavnom pojavljuju zajedno, te na taj način dati osnovu za precizniji pristup u njihovu zbrinjavanju.
Zaprimljen: 7. ožujka 2021. Prihvaćen: 14. Svibnja 2021.

Adresa za dopisivanje Iva Z. Alajbeg

Sveučilište u Zagrebu Stomatološki fakultet Zavod za mobilnu protetiku Gundulićeva 5, 10000 Zagreb ialajbeg@sfzg.hr

MeSH pojmovi: poremećaji čeljusnog zgloba; dobne skupine Ključne riječi: temporomandibularni poremećaji, orofacijalna bol, kronična bol

\section{References}

1. Ohrbach R, Dworkin SF. The evolution of TMD diagnosis: past, present, future. J Dent Res. 2016 Sep;95(10):1093-101.

2. Greene CS, Lerman MD, Sutcher HD, Laskin DM. The TMJ paindysfunction syndrome: heterogeneity of the patient population. J Am Dent Assoc. 1969 Nov;79(5):1168-72.

3. Fillingim RB, Ohrbach R, Greenspan JD, Knott C, Dubner R, Bair E, et al. Potential psychosocial risk factors for chronic TMD: descriptive data and empirically identified domains from the OPPERA case-control study. J Pain. 2011 Nov;12(11 Suppl):T46-60.
4. Michelotti A, Cioffi I, Festa P, Scala G, Farella M. Oral parafunctions as risk factors for diagnostic TMD subgroups. J Oral Rehabil. 2010 Mar;37(3):157-62.

5. Okeson JP. Temporomandibularni poremećaji i okluzija. Zagreb: Medicinska naklada; 2008.

6. Manfredini D, Chiappe G, Bosco M. Research diagnostic criteria for temporomandibular disorders (RDC/TMD) axis I diagnoses in an Italian patient population. J Oral Rehabil. 2006 Aug;33(8):5518. 
7. Ferrando M, Andreu Y, José Galdón M, Durá E, Poveda R, Vincente Bagán J. Psychological variables and temporomandibular disorders: Distress, coping, and personality. Oral Surg Oral Med Oral Pathol Oral Radiol Endod. 2004;98(2):153-60.

8. Dworkin SF and LeResche L. Research diagnostic criteria for temporomandibular disorders: Review, criteria, examinations and specifications, critique. J Craniomandib Disord 1992;6:301-55.

9. Von Korff M, Dworkin SF, Le Resche L, et al. An epidemiologic comparison of pain complaints. Pain 1988;32:173-83.

10. Kashima K, Rahman OI, Sakoda S, Shiba R. Increased pain sensitivity of the upper extremities of TMD patients with myalgia to experimentally-evoked noxious stimulation: possibility of worsened endogenous opioid systems. Cranio. 1999 Oct;17(4):241-6.

11. Miloro M, Larsen P, Ghali GE, Waite P. Peterson's principles in oral and maxillofacial surgery. Med J Armed Forces India. 2006;62(1):89.

12. Rieder CE, Martinoff JT, Wilcox SA. The prevalence of mandibular dysfunction. Part I: Sex and age distribution of related signs and symptoms. J Prosthet Dent. 1983;50(1):81-8.

13. Schiffman E, Ohrbach R, Truelove E, et al. Diagnostic Criteria for Temporomandibular Disorders (DC/TMD) for Clinical and Research Applications: recommendations of the International RDC/ TMD Consortium Network* and Orofacial Pain Special Interest Groupt. J Oral Facial Pain Headache. 2014;28(1):6-27.

14. Valesan LF, Da-Cas CD, Réus JC, Denardin ACS, Garanhani RR, Bonotto D, et al. Prevalence of temporomandibular joint disorders: a systematic review and meta-analysis. Clin Oral Investig. $2021 \mathrm{Feb} ; 25(2): 441-453$.

15. Lovgren A, Haggman-Henrikson B, Visscher CM, Lobbezoo F, Marklund, Wanman A. Temporomandibular pain and jaw dysfunction at different ages covering the lifespan: a population based study. Eur J Pain. 2016 Apr;20(4):532-40.

16. Bhat S. Etiology of temporomandibular disorders: the journey so far. J Int Dent. 2010;12(4):88-92.

17. Ribeiro-Dasilva MC, Line SRP, Santos M, et al. Estrogen Receptor- $\alpha$ Polymorphisms and Predisposition to TMJ Disorder. J Pain. 2009;10:527-33.

18. Alajbeg IZ, Vrbanović E, Lapić I, Alajbeg I, Vuletić L. Effect of occlusal splint on oxidative stress markers and psychological aspects of chronic temporomandibular pain: a randomized controlled trial. Sci Rep. 2020 Jul 3;10(1):10981.

19. Gikić M, Vrbanović E, Zlendić M, Alajbeg IZ. Treatment responses in chronic temporomandibular patients depending on the treatment modalities and frequency of parafunctional behavior. J Oral Rehabil. 2021 Apr 2.

20. Ouanounou A, Goldberg M, Haas DA. Pharmacotherapy in Temporomandibular Disorders: A Review. J Can Dent Assoc. 2017;83:h7

21. Derwich M, Mitus-Kenig M, Pawlowska E. Orally Administered NSAIDs-General Characteristics and Usage in the Treatment of Temporomandibular Joint Osteoarthritis-A Narrative Review. Pharmaceuticals (Basel). 2021 Mar 5;14(3):219.

22. Nicholas M, Vlaeyen JWS, Rief W, Barke A, Aziz Q, Benoliel R, et al. IASP Taskforce for the Classification of Chronic Pain. The IASP classification of chronic pain for ICD-11: chronic primary pain. Pain. 2019 Jan;160(1):28-37.

23. Manfredini D, Guarda-Nardini L, Winocur E, Piccotti F, Ahlberg J, Lobbezoo F. Research diagnostic criteria for temporomandibular disorders: a systematic review of axis I epidemiologic findings. Oral Surg Oral Med Oral Pathol Oral Radiol Endod. 2011;112(4):453-62.

24. Yadav S, Yang Y, Dutra EH, Robinson JL, Wadhwa S. Temporomandibular Joint Disorders in Older Adults. J Am Geriatr Soc. 2018;66(6):1213-17.

25. Lora VR, de Canales GL, Goncalves LM, Meloto CB, Barbosa CM. Prevalence of temporomandibular disorders in postmenopausal women and relationship with pain and HRT. Braz Oral Res. 2016 Aug 22;30(1):e100.

26. Liu F, Steinkeler A. Epidemiology, diagnosis, and treatment of temporomandibular disorders. Dent Clin North Am. 2013;57(3):465 79.

27. Mazzetto MO, Rodrigues CA, Magri LV, Melchior MO, Paiva G. Severity of TMD related to age, sex and electromyographic analysis. Braz Dent J. 2014;25(1):54-8.
28. Atsü SS, Ayhan-Ardic F. Temporomandibular disorders seen in rheumatology practices: A review. Rheumatol Int. 2006 Jul;26(9):781-7.

29. Carvalho CM, de Lacerda JA, dos Santos Neto FP, Cangussu MC, Marques AM, Pinheiro AL. Wavelength effect in temporomandibular joint pain: a clinical experience. Lasers Med Sci. 2010;25(2):229-32

30. Carlsson GE, LeResche L. Epidemiology of temporomandibular disorders. In: Sessle BJ, Bryant PS, Dionne RA, editors. Temporomandibular Disorders and Related Pain Conditions. Seattle: ASP Press; 1999.

31. Sönmez H, Sari S, Oksak Oray G, Camdeviren H. Prevalence of temporomandibular dysfunction in Turkish children with mixed and permanent dentition. J Oral Rehabil. 2001;28(3):280-5.

32. Agerberg G, Inkapööl I. Craniomandibular disorders in an urban Swedish population. J Craniomandib Disord. 1990;4(3):154-64.

33. Michelotti A, lodice $G$. The role of orthodontics in temporomandibular disorders. J Oral Rehabil. 2010 May;37(6):411-29.

34. Manfredini D, Stellini E, Gracco A, Lombardo L, Nardini LG, Siciliani G. Orthodontics is temporomandibular disorder-neutral. Angle Orthod. 2016 Jul;86(4):649-54.

35. LeResche L. Epidemiology of temporomandibular disorders: implications for the investigation of etiologic factors. Crit Rev Oral Biol Med. 1997;8(3):291-305.

36. Häggman-Henrikson B, Liv P, Ilgunas A. Increasing gender differences in the prevalence and chronification of orofacial pain in the population. Pain. 2020 Aug;161(8):1768-1775.

37. Ebrahim S, Montoya L, Busse JW, Carrasco-Labra A, Guyatt GH; Medically Unexplained Syndromes Research Group. The effectiveness of splint therapy in patients with temporomandibular disorders: a systematic review and meta-analysis. J Am Dent Assoc. 2012;143(8):847-57.

38. Nagata K, Maruyama H, Mizuhashi R, Morita S, Hori S, Yo koe T, Sugawara Y. Efficacy of stabilisation splint therapy combined with non-splint multimodal therapy for treating RDC/TMD axis I patients: a randomised controlled trial. J Oral Rehabil. 2015;42(12):890-9.

39. Martins WR, Blasczyk JC, Aparecida Furlan de Oliveira M. Efficacy of musculoskeletal manual approach in the treatment of temporomandibular joint disorder: a systematic review with metaanalysis. Man Ther. 2016 Feb;21:10-7.

40. van Grootel RJ, Buchner R, Wismeijer D, van der Glas HW. Towards an optimal therapy strategy for myogenous TMD, physiotherapy compared with occlusal splint therapy in an RCT with therapy-and-patient-specific treatment durations. BMC Musculoskelet Disord. 2017;18(1):76.

41. Vrbanović E, Alajbeg IZ. Long-term Effectiveness of Occlusal Splint Therapy Compared to Placebo in Patients with Chronic Temporomandibular Disorders. Acta Stomatol Croat. 2019;53(3):195-206.

42. Sommer C. Pharmakologische Behandlung orofazialer Schmerzen [Pharmacotherapy of orofacial pain]. Schmerz. 2002 Sep;16(5):381-8.

43. Ouanounou A, Goldberg M, Haas DA. Pharmacotherapy in Temporomandibular Disorders: A Review. J Can Dent Assoc. 2017 Jul; $83:$ h7.

44. Dionne RA. Pharmacologic treatments for temporomandibular disorders. Oral Surg Oral Med Oral Pathol Oral Radiol Endod. 1997;83(1):134-42.

45. Vogl TJ, Lauer HC, Lehnert T, Naguib NN, Ottl P, Filmann N, et al. The value of MRI in patients with temporomandibular joint dysfunction: Correlation of MRI and clinical findings. Eur J Radiol. 2016 Apr;85(4):714-9.

46. Wright AR, Gatchel RJ, Wildenstein L, Riggs R, Buschang P, Ellis $\mathrm{E}$ 3rd. Biopsychosocial differences between high-risk and low-risk patients with acute TMD-related pain. J Am Dent Assoc. 2004;135(4):474-83.

47. Gatchel R J, Stowell AW, Wildenstein L, Riggs R, Ellis E. Efficacy of an early intervention for patients with acute temporomandibular disorder-related pain. Am Dent Assoc. 2006 Mar;137(3):339-47.

48. Pimenta e Silva Machado L, de Macedo Nery MB, de Góis Nery C, Leles CR. Profiling the clinical presentation of diagnostic characteristics of a sample of symptomatic TMD patients. BMC Oral Health. 2012 Aug 2;12:26. 